\title{
Fæsteskov i Åbenrå amt i 18. århundrede
}

\section{Af Niels Black Hansen}

Den forskel, som kendes mellem s e lvejer- og $f æ s$ t eb o n d e fra tidligere århundreder, udjævnedes som bekendt mere og mere, så der tilsidst — i hvert fald i praksis — næppe var noget virkelig dybtgående skel af økonomisk ${ }^{1}$ ) betydning, selv om der blev løst fæstebrev til helt ind i den prøjsiske tid og betalt indfæstningspenge henholdsvis årlig afgift.

Amtmand v. B e hr (1756-1768) udtaler i 1768, at alle fæstegårde under Åbenrå (og Løgumkloster) er a r v e l i g e, men endnu hundrede år senere optoges dog stadig i fæstebrevene en bestemmelse om, at indehaveren af en fæstegård ikke uden amtmandens minde under fæstets fortabelse må pantsætte, udleje eller sælge gården eller noget af dens tilliggende. Amtmand v. Behr fremhæver ganske vist, at ejendomsbønderne også skulde have tilladelse fra rentekammeret eller amtet, når de vilde sælge noget af deres tilliggende. Men det er s k ov e n, det i denne korrespondance drejer sig om. I Åbenrå amt hører, skriver v. Behr, til nogle gårde ingen, til nogle ringe, til andre lidt ("mäsige") og til få betydeligt skovareal. Men de få har mindre ager og eng og må holde sig til skoven for at kunne svare afgifterne.

1) At indehaverne af tillidshverv i regelen var selvejere, kunde tyde på et vist socialt skel. Dog var regelen ikke uden undtagelser. Săledes var på Bundesens gård i Genner, som i 1700 på grund af skatterestancer var gået over i fæsteforhold, både Jens Bundesen VII. og Jens Bundesen VIII. sognefogeder og amtsfuldmægtige (H. Hejselbjerg-Paulsen, ,Sønderjydske Slægter «, s. 239). 
Det var med hensyn til dispositionsretten oyer skoven, at $f$ æsterenstod tilbage overfor ejer e n, og denne forskel holdt sig til op i det 19. århundrede.

Lige siden 1713, da kongen besatte den gottorpske del af Sønderjylland, havde det got tor pske styre strammet tøjlerne noget for selvejerne. Ifølge en forordning af 14.11. 1710 blev selvejerne for så vidt stillet på lige fod med fæsterne, som de ligesom disse kun måtte hente træ fra deres skov efter udvisning, medens undersåtterne i de kongelige amter ikke var underkastet denne, såfremt de viste mådehold og kun tog til husbehov.

Den energiske overpræsident i Altona C. D. G. Z. R e v e n tlow, der i 1713 som over-jægermester stod i spidsen for tilsynet med statens skove, udtaler i en skrivelse af 11. 10.1713 til amtmændene i de hidtidige gottorpske amter, at de herskende insolvente tilstande er af en sådan karakter, at der må skrides ind med skarpe forholdsregler. Enhver skovbetjent skal agte på og indestå for sit eget distrikt. Uvedkommende skal anholdes, heste og hunde om fornodent skydes på stedet.

Amtsinspektar i det kongelige amt Gottorp kammerråd L ü d e r s, der i 1720 købte Risgård i det tidligere gottorpske amt Åbenrå, havde da heller ikke let ved at finde sig i den indskrænkning af ejendomsretten, som amtmand v. Mass ow (1723-52) tilsyneladende har haft noget svært ved at give afkald på. Ganske vist overså eller fortiede kammerråd Lüders, at der til Risgård ikke alene hørte ejendoms-, men o g s å fæ s t es k o v, og det viste sig iøvrigt, at v. Massow havde haft al grund til at se ham på fingrene. Men der var også andre undersåtter i Åbenrå amt, som endnu en halv menneskealder efter overgangen til kongelig administration måtte henvende sig til rentekamret med klage over, at forordningen af 1710 stadig blev håndhævet i amtet. Over-jægermester G r a m, som kammeret afæskede en forklaring, udtalte, at der ikke kunde være tale om fæste- 
bestemmelser for selvejere, såsom det ikke var bekendt, at den omhandlede forordning havde kongelig bekræftelse.

Forbigånde synes rentekammeret at have gjort en svag indrommelse $i$ retning af at beskære selvejernes rettigheder. I en besked til indbyggerne i A benrå amt af 29.4.1730 udtales nemlig under udtrykkelig henvisning til den omtalte fyrstelige forordning af 1710 , at selvejerne er underkastet udvisningstvang, dog, i henhold til kongelig resolution af 19.3.1729, uden stem pelaf $\mathrm{g}$ if $t$.

I 1730erne var der en a l mindelig forst-og jagt f o r o r d n in g under forberedelse, og der er bevaret et foreløbigt udkast af 1734 med betænkninger fra amterne Husum, Gottorp og Rendsborg. I en af disse betænkninger hedder det bl. a., at man som straf for skovforseelser vilde foretrække trillebør fremfor spidsrod. Man kan alene heraf tænke sig, hvorledes man dengang tog på den slags ting. Den endelige forordning for hertugdømmerne kom under 24. 4. 1737. Straffebestemmelserne er også her skrappe nok. Bøderne ligger mellem 3 og 20 rdl. pr. træ. Naturligvis skal desforuden træet betales efter taksationsværdi. Hvem der ikke kan betale, skal stå i nogle timer om søndagen ved skampælen på vejen til kirken i halsjern og med et „mådeligt" stykke træ under armen eller også arbejde med trillebør i en måned for hver $10 \mathrm{rdl}$. Der er, hedder det i $\S 25$, begået en sådan rovdrift især med egetræerne, at alle og enhver, det være sig ejere eller fæstere, præster ${ }^{2}$ ) eller hvemsomhelst advares på det kraftigste. Misbrug vil blive behandlet som tyveri. Man kan, som man gør det andetsteds, efter indhentet approbation anlægge teglovne og brænde sten til byggeriet. Det lyder næsten som en anakronisme, når landmændene gøres solidarisk ansvarlige for skovene, og forsømt agtpågivenhed trues med samme straffe som overtrædelse. Enhver kan og skal udøve

2) Skampæl-straffen må præst og degn dog vist have været undtagne fra, da de jo var lovligt forhindret under kirketid. I påkommende tilfælde må man have affundet sig med dem på anden måde, hvis de ikke var i stand til at betale. 
politimyndighed ved at anholde gerningsmændene, eventuelt med hest og vogn. For angiveri udsættes præmie, hvoraf dog halvdelen tilfalder den kongelige kasse. Der er, som man ser, intet helt nyt under solen.

Hvad forskellen mellem selvejer og fæster angår, hedder det ( $\$ 36$ ), at selvejeren fra arilds tid med rette har kunnet $f æ l d e$ et og andet $t r æ i$ sin skov til $\mathrm{h} u \mathrm{~s} b \mathrm{eh}$ ov. Ved misbrug skal han i første omgang betale det $\mathrm{h}$ a $\mathrm{lve}$ beløb af de under straffebestemmelser fastsatte bøder og i gentagelsestilfælde $m$ iste dispositionsretten for livstid (altså være ligestillet med en fæ$\mathrm{s}$ t e r). Forskellen mellem de to kategorier understreges kraftigt $i$ en skrivelse fra rentekammeret til amtmand v. Massow 31. 5. 1732, hvor det udtales, at selvejerne ik ke med nogen ret kan underkastes den tvang, som indehaverne af $f æ s t e s k$ ov står under, al den stund selvejerundersåtterne $\mathrm{i}$ hertugdømmernes kongelige amter ingensinde havde fået træ udvist $\mathrm{i}$ deres ejendomsskove og ingenlunde var indskrænkede $\mathrm{i}$ deres nedarvede frihed, såfremt de ikke gjorde sig skyldige i misbrug, hvorimod $\mathrm{f} æ \mathrm{~s}$ t e-u nd e r s a t t e rne ikke kunde gørekrav påslig frihed, da fæsteskov tilhørte herskabet "privative“. Hvem der forgriber sig på fæsteskov, skal i henhold til kongelig resolution ansættes til bøde eller underkastes legemlig straf.

Ved befolkningens uforstandige ødslen med den kostbare egebestand i skovene var disse blevet udtyndede $i$ betænkelig grad. Ifølge forordningen af 1737 måtte ingen præst ægtevie en ung mand, der ikke kunde forelægge attest for, at han havde plantet 10 ege- og 15 bøgetræer eller erlagt henholdsvis 1 rdl. og 32 sk. pr. plante. Det kunde altså blive en sum på 20 rdl., som den unge mand skulde af med på denne konto. I en skrivelse fra rentekammeret af 20.6. 1767 til amtmand v. Behr bestemtes det, at fæstebønderne selv skulde så agern $\mathrm{i}$ indhegnede marker, ellers fik de ikke træ udvist til deres huse. 
Århundredets sidste halvdel med dets landbrugsreformer bragte ingen lempelse for fæsterne. I et pro memoria fra amtshuset i Åbenrå til rentekammeret af 14. 5. 1789 frakendes indehaverne af fæsteskov enhver ret til at disponere på egen hånd, selv om de eller deres forgængere har plantet træerne og fảet dem til at gro, det være sig til byggemateriale eller til brænde.

Indehaverne af fæsteskov forsøgte ikke så sjældent at handle sig tilrette med rentekammeret. Matthias Jacobsen af Brunde bød i 1759 kammerat $400 \mathrm{mk}$. for at blive selvejer. Han fik afslag. Efter et bud på $200 \mathrm{rdl}$. opfordrede rentekammeret amtet til en indberetning. Assessor (amtsforvalter) Mor te n$\mathrm{s}$ e $\mathrm{n}$ og Hegereiter (skovrider) Lo $\mathrm{r}$ e $\mathrm{n} \mathrm{t} \mathrm{z}$ e $\mathrm{n}$ sattes $\mathrm{i}$ bevægelse. I Mortensens skøn hedder det, at ansegeren kun vil blive ejer for skovens skyld. Men i så fald vil han måske hugge løs, som de brundinger og søesinger bønder plejer. Amtmanden, v. Behr, skriver til rentekammeret: Forskellen mellem en selvejer og en fæster er ikke stor i dette amt. Begge er arvelige og har bestemte afgifter. Den eneste fordel, selvejeren har forud, er denne, at han i sin skov kan fælde træ uden udvisning, så længe han går frem med varsomhed, og at han ikke behøver at erlægge mæsknings- og stempelafgift. Amtmandens anbefalende indberetning blev imidlertid ikke taget til følge af rentekammeret.

I 1770 gør rentekammeret baron v. We del (amtm. i Åb. 1768-72) opmærksom på, at forordningen om udskiftning af samme år (Einkoppelungs-Verordnung) er blevet misforstået. Det er kun selvejerbonderne, der maa fjerne krat og budskads i deres lokker.

Et enkelt eksempel til på forskellen henimod slutningen af århundredet. H a n s B r u h n på Strågård ved Åbenrå - fader til den kendte agent Jørgen Bruhn i Åbenrå - førte en årelang kamp for at få sin skov anerkendt som selveje. Hans bedstefader havde været selvejer, men ved overgangen i 1713 havde han efter opfordring måttet indsende alle sine papirer til Kø- 
benhavn. Man havde afkrævet ham et beløb på $100 \mathrm{rdl}$. for konfirmationen af ejendomsbrevet. En sådan sum havde han ikke set sig i stand til at betale, og gården og dermed også skoven var på denne måde blevet fæstegods. I 1789 vilde imidlertid myndighederne lægge den formentlige fæsteskov til Jørgensgårdskov. Hans Bruhn svarede man på hans indvendinger, at det var hans sag at føre beviset for ejendomsretten. Det lød besynderligt, hedder det, at bedstefaderen i sin tid ikke havde sørget for at få bekræftede afskrifter af de papirer, han havde indsendt. (Måske en naturlig ting for embedsmændene, men en såre fjerntliggende tanke for Hans Bruhns bedstefader, vilde man være tilbøjelig til at sige. Men dengang har verificerede afskrifter vistnok spillet en større rolle). Der blev skrevet frem og tilbage, indhentet skøn fra de forskellige instanser, opmålt og optegnet skitser og udfærdiget designationer, og resultatet blev at Hans Bruhn måtte betale $\% 3$ af taksationsværdien, 981 rdl., som han nådigst fik lov til at erlægge i flere terminer mod en forrentning af 4 pct. Så skæbnesvangert kunde det blive endnu i slutningen af århundredet ikke at have sit ejendomsbevis $i$ orden.

I begyndelsen af 19. århundrede er rentekammeret tilsyneladende ikke uvillig til at gøre forretning med fæsteskov ved at lade indehaverne betale for at blive selvejere. Rentekammeret tiltræder under 7. 7. 1807 i skrivelse til amtmand v. B I ü ch e r (1802-08) og landkommissionen salg af fæsteskov til $\mathrm{Chri}$ stian Jessen Brode, Jürgen Jessen Ellberg og $\mathrm{N}$ is Bertelsen $\mathrm{Maag}$ for $2 / 3$ af taksationsværdien, som er henholdsvis 119 rdl. 12 sk., 229 rdl. 24 sk. og 166 rdl. 16 sk. Fæstere må, skriver hofjægermester v. $\mathrm{K} \mathrm{rog} \mathrm{h}$ under 18. 11 . 1810 til amtmand v. Stem an n (1808-30), kun få, hvad de står opført til i skovregistret; hvis de vil have mere, må de betale fuld pris. Ellers vilde der, mener v. Krogh, i k k e væ r e f o r sk el nok mellem dem, der har tilbagekøbt fæsteskov, og fæstebønder, som „ikke har villet modtage denne velgerning.“ 
Forskellen mellem selvejere og fæstere gælder på samme måde $\mathrm{m}$ os e $\mathrm{n} \mathrm{e}$, hvor man i tidligere tider havde gravet på må og få uden hensyn til efterkommerne. Når tiderne var trange og pengene - ikke mindst på grund af de offentlige byrder — få, var det at fælde træer og grave tørv den nemmeste og hurtigste måde at slå penge på. Men derfor var også regeringen interesseret $i$ netop på dette punkt længst muligt at opretholde den indskrænkning af dispositionsretten, som fæstebrevet hjemlede.

Det var den største part af landbrugerne i Åbenrå amt, der ramtes af bestemmelserne for fæsteskov. I 1732 (Bonden- $u$. Feste-Register des Amts Apenrade) var forholdet mellem selvejergrund og fæstejord i amtet udtrykt i plovtal omtrent 1 : 2. For selvejernes vedkommende er plovtallet for skovejere $65^{3 / 4}$. Fæstegårdene med skovtilliggende er ikke opgivet. Men man overdriver i hvert fald ikke, når man går ud fra, at fæsternes overlegenhed i plovtal har været mindst ligeså stor i skovegnene som i amtet som helhed. I Varnæs birk var der i 1789 (indberetning fra amtshuset til rentekammeret) kun fæsteskov, hvilket ikke kan overraske ${ }^{8}$ ).

3) De her benyttede akter beror på det sønderjydske landsarkiv og findes let ved hjælp af den systematisk ordnede fortegnelse over fra Kiel afleverede arkivalier under Åbenrå amtsarkiv.

For den læser, som måtte $\emptyset$ nske at beskæftige sig mere indgående med dette spørgsmål, som ikke synes at have været genstand for nøjere unders $\varnothing$ gelse, kan der tilf $\varnothing j e s$, at der udover afleveringerne fra Kiel på nævnte landsarkiv findes et par større pakker om fæste og fæsteafløsning i Ảbenrå amtstue- og Åbenrå skovriderarkiv. Man får her yderligere bekræftet, hvilken rolle skoven har spillet og hvor tiltrækkende den har været for fæsterne på den ene side, men hvor retarderende den på den anden har virket på rentekammeret, hvor gerne end dette så afløsningssummerne glide ind $\mathrm{i}$ den kasse, hvis tilstand kammeret såvist ikke sidst plejede at tænke på ved sine overvejelser. At udviklingen måtte føre hen mod fuldstændig afløsning i 19. århundrede, kunde der efter tidehvervet omkring århundredskiftet ikke godt være tvivl om.

Et rigt materiale findes også i rentekammerarkivet i Rigsarkivet. (Denne henvisning skyldes hr. landsarkivar J. Hvidtfeldt). 